\title{
A fine-grained sediment budget for the Sylt-Rømø tidal basin
}

\author{
M. Pejrup, M. Larsen \& K. Edelvang \\ Institute of Geography, University of Copenhagen; Øster Voldgade 10, \\ DK-1350 Copenhagen K, Denmark
}

\begin{abstract}
A budget for net accumulation of fine-grained sediment $(<63 \mu \mathrm{m})$ has been set up for the Sylt-Rømø tidal basin. Net accumulation within the basin was computed from ${ }^{210} \mathrm{~Pb}$ core dating and mapping of the intertidal and supratidal surface sediments. It was found that a yearly mean value of $58 \cdot 10^{3}$ tons of sediment was deposited in the tidal basin. The largest sediment source for the net input of fine-grained sediment is the North Sea contributing about $64 \%$ to the net budget; the fluvial input and primary production contribute $14 \%$ and $15 \%$, respectively. Local salt marsh erosion accounts for about $5 \%$ of the budget and atmospheric deposition for only $2 \%$. The total amount of sediment deposited in the investigated area was low compared with earlier investigations in the Wadden Sea. This is explained partly by the intensive diking of the natural salt marshes fringing the area in the past, and partly by the exposed conditions of most of the intertidal flats. An index describing the trapping efficiency of the water exchanged between the North Sea and the SyltRømø tidal area is defined as the ratio between yearly net sediment input from the North Sea and yearly exchanged water volume between the tidal basin and the sea. This index shows that in the Sylt-Rømø tidal basin, fine-grained suspended sediment "filters" out of the exchanged sea water at a rate that is 12 times lower than in the Grådyb tidal basin. It is concluded that the net deposition of fine-grained sediment in a tidal basin is mainly a function of physiographical and hydrodynamical parameters and to a lesser degree of sediment availability.
\end{abstract}

\section{INTRODUCTION}

Shallow estuarine areas are known to import large quantities of fine-grained sediment from the adjacent seas (cf. Schubel \& Carter, 1984; Leonard et al., 1994; French et al., 1994). This is also true for tidal areas in the Wadden Sea (cf. Bartholdy \& PheifferMadsen, 1985; Pejrup, 1988a; Breuning-Madsen, 1995; and Larsen et al., 1996). The accumulation of fine-grained sediment in the Wadden Sea is mainly caused by the settling- and scour lag mechanisms as described by Van Straaten \& Kuenen $(1957,1958)$ and Postma (1967). However, other processes such as aggregation of fine-grained sediment particles may also be important. The role of salt flocculation has been described as potentially important by Pejrup $(1988 b, 1991)$ and bioaggregation in the form of faecal pellets has been shown to be important (cf. Haven \& Morales-Alamo, 1972; Edelvang \& Austen, 1997).

Fine-grained sediment budgets have only been set up for a small number of tidal areas in the Wadden Sea. For Grådyb, the northernmost tidal area, Bartholdy \& PheifferMadsen (1985) computed an annual net accumulation of $142 \cdot 10^{3}$ tons of fine-grained sediment; and Larsen et al. (1996) computed a net accumulation of 2 tons for the small 
tidal area Königshafen which is a part of the Sylt-Rømø tidal basin. On the basis of literature studies, Eisma \& Irion (1988) estimated the net accumulation of fine-grained sediment $(<125 \mu \mathrm{m})$ in the whole Wadden Sea, including the Wash on the East Anglian coast, to be $5 \cdot 10^{6}$ t/year.

Apart from the above-mentioned studies, only few attempts have been made to establish fine-grained sediment budgets for other tidal areas in the Wadden Sea. Extrapolating from the figures given by Bartholdy \& Pheiffer-Madsen (1985), the net accumulation in the Wadden Sea would amount to approximately $8 \cdot 10^{6} \mathrm{t} /$ year which is 1.6 times that found by Eisma \& Irion (1988). Flemming \& Nyandwi (1994) suggested that some Wadden Sea tidal areas may be depleted of fine-grained sediments because of human activities such as land reclamation in the area. On the basis of a detailed study of settling velocities of bottom sediments behind the barrier islands of Spiekeroog and Baltrum they found that grain sizes less than $3.5 \varnothing(88 \mu \mathrm{m})$ were underrepresented in the bottom sediments of the tidal flats compared to other less manipulated tidal basins. Similar results were presented by Dronkers (1986), who showed that intense diking of the Oosterschelde estuary reversed the net import of fine-grained sediments to a net export. These findings emphasize the need for further studies of fine-grained sediment budgets. The objectives of this study are to set up a budget for the net accumulation of fine-grained sediment for the Sylt-Rømø tidal basin, and to compute the relative importance of the different sediment sources.

\section{STUDY AREA}

The Sylt-Rømø tidal basin covers an area of approximately $400 \mathrm{~km}^{2}$ of which the intertidal area comprises about $45 \%$ (Fig 1). The tide is semi-diurnal with an average tidal range of about $1.8 \mathrm{~m}$, classifying it as a micro-tidal estuary according to Davis (1964) or lower meso-tidal after Hayes (1979). The tidal prism is about $530 \cdot 10^{6} \mathrm{~m}^{3}$ and maximum tidal current velocities of about $2 \mathrm{~m} / \mathrm{sec}$ are measured in the tidal inlet, decreasing to about $0.2 \mathrm{~m} / \mathrm{sec}$ on the tidal flats in the inner parts of the area (Edelvang, 1995). The tidal basin is restricted both to the north and to the south by artificial dams, the Rømø dam and Hindenburg dam, respectively.

The bottom sediments in the intertidal zone range from sand flats with more than $95 \%$ sand, mixed mud flats containing $10-50 \%$ sand, to mud flats containing more than $50 \%$ fine-grained sediments.

Two small rivers discharge through sluice gates into the tidal area. The rivers Brede $\AA$ and Vidă have catchment areas of $464 \mathrm{~km}^{2}$ and $1364 \mathrm{~km}^{2}$, respectively. The mean freshwater discharge from these two rivers amounts to about $1 \cdot 10^{6} \mathrm{~m}^{3}$ or $0.2 \%$ of the tidal prism over one tidal cycle.

Most of the natural salt marshes fringing the area have been diked, and only about $10 \mathrm{~km}^{2}$ of undiked salt marshes are currently exposed to inundation during storm surges.

\section{METHODS}

\section{Total net accumulation}

The total net accumulation has been estimated from ${ }^{210} \mathrm{~Pb}$ core dating of the sediment on the intertidal flats and on the salt marsh. ${ }^{210} \mathrm{~Pb}$ is a natural radioactive $\mathrm{Pb}$-isotope existing in the atmosphere. It is the product of the decay of ${ }^{238} \mathrm{U}$ in the earth crust decaying 


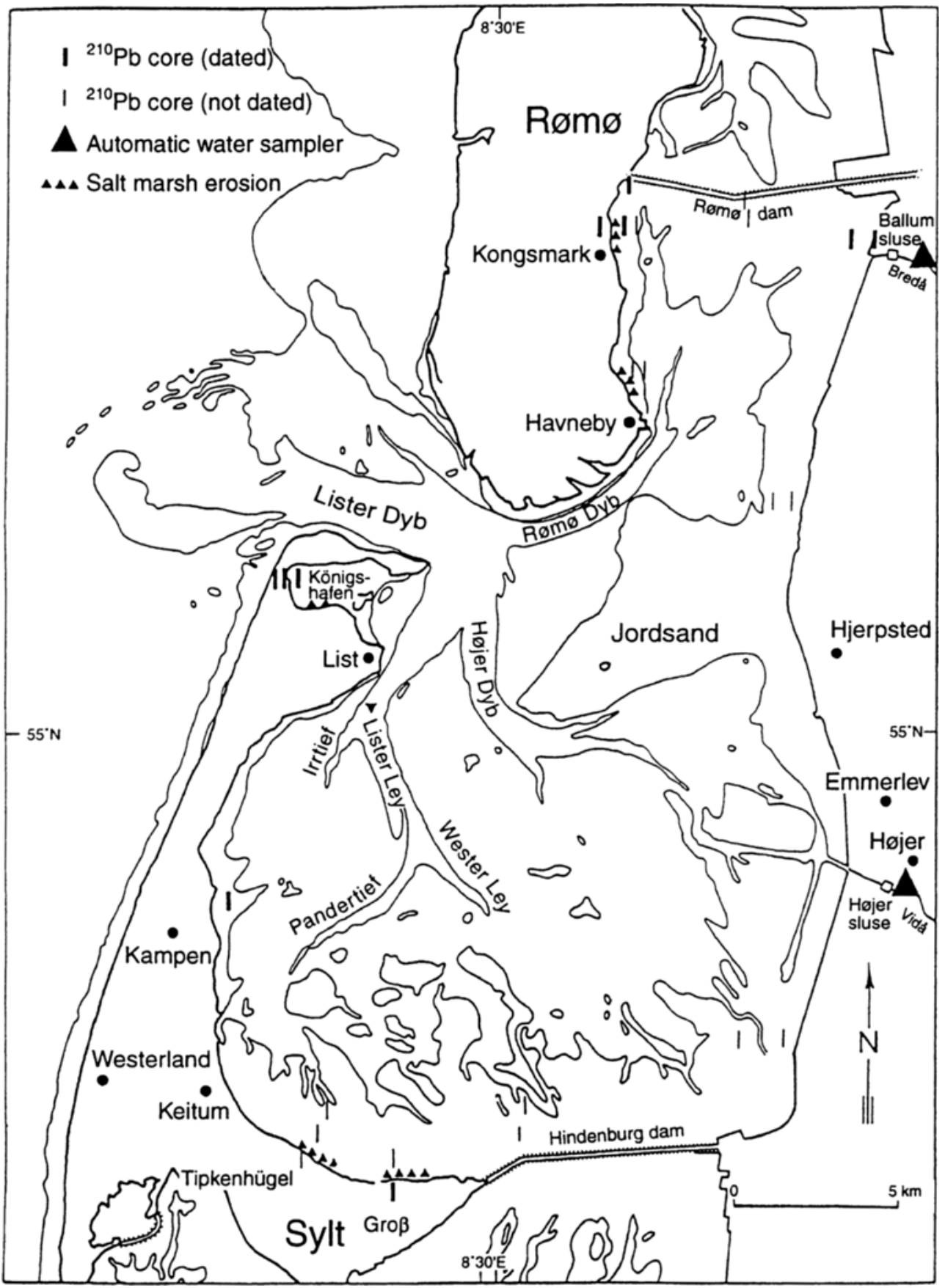

Fig. 1. Map of the investigated tidal basin with indication of sites for sediment core sampling, water sampling stations, and sites for measuring salt marsh erosion 
to ${ }^{226} \mathrm{Ra}$ and further to the gas ${ }^{222} \mathrm{Rn}$ which is emitted from the earth crust to the atmosphere, where it further decays to ${ }^{210} \mathrm{~Pb}$ that is returned to the earth surface by precipitation. When ${ }^{210} \mathrm{~Pb}$ is introduced in the estuarine environment it adheres to the cohesive sediment particles suspended in the water and is transported and deposited together with these particles. The sediment cores were collected as box cores in the supratidal areas and as normal sediment cores using aluminium tubes with $8 \mathrm{~cm}$ diameter in the intertidal areas. After sampling, each core was split vertically into two halves and subsequently cut horizontally into $1 \mathrm{~cm}$ slices. The method is described in greater detail by Larsen et al. (1996).

The measured ${ }^{210} \mathrm{~Pb}$ activity in the sediment can be divided into (a) supported and (b) unsupported activity. The supported part originates from the decay of ${ }^{222} \mathrm{Rn}$ within the sediment and the unsupported ${ }^{210} \mathrm{~Pb}$ activity originates from ${ }^{210} \mathrm{~Pb}$ precipitated to the surface. The half-life of this isotope is 22.3 years and it is assumed that a constant amount of ${ }^{210} \mathrm{~Pb}$ is deposited from the atmosphere every year. The age of the different sediment layers can be computed by measuring the unsupported ${ }^{210} \mathrm{~Pb}$ activity from each layer, thereby establishing a vertical profile of the ${ }^{210} \mathrm{~Pb}$ activity. The ${ }^{210} \mathrm{~Pb}$ activity was measured as ${ }^{210} \mathrm{Po}$ activity by $\alpha$-spectrometry and ${ }^{210} \mathrm{~Pb}$ activity was assumed to be equal to the measured ${ }^{210} \mathrm{Po}$ activity. To calculate the age of the different sediment layers, the Constant Rate of Supply method (C.R.S.) is used, where the flux of ${ }^{210} \mathrm{~Pb}$ is assumed to be constant in time for the investigated area. This method is recommended by several authors for fine-grained sediment accumulation areas with variable deposition rates (e.g. Appleby \& Oldfield, 1978; Pheiffer-Madsen \& Sørensen, 1979; El-Daoushy, 1988). Subsequently, the total accumulation rate of sediment can be estimated from the slope of the activity profile beneath the mixing layer at the top of the sediment core. The vertical activity profile is described by a mathemathical model based on the following advectiondiffusion equation:

$$
\frac{\mathrm{dS}}{\mathrm{dt}}=\mathrm{D} \cdot \frac{\mathrm{d}^{2} \mathrm{~S}}{\mathrm{dz^{2 }}}-\mathrm{w} \cdot \frac{\mathrm{dS}}{\mathrm{dz}}-\mathrm{l} \cdot \mathrm{S}
$$

Where $\mathrm{S}$ is the activity of ${ }^{210} \mathrm{~Pb}(\mathrm{dpm} / \mathrm{g})$

$\mathrm{D}$ is the mixing coefficient ( $\mathrm{cm}^{2} /$ year)

$\mathrm{z}$ is the depth beneath surface $(\mathrm{cm})$

$\mathrm{w}$ is the linear accumulation rate $(\mathrm{cm} /$ year)

1 is the decaying constant for ${ }^{210} \mathrm{~Pb}\left(\mathrm{year}^{-1}\right)$ and

$\mathrm{t}$ is the time (years)

Subsamples from the other core sections were used for grain size analysis. Each sample was divided by wet sieving into a fraction coarser than $63 \mu \mathrm{m}$ and one finer than $63 \mu \mathrm{m}$ after it had been suspended in $0.002 \mathrm{M} \mathrm{Na}_{4} \mathrm{P}_{2} \mathrm{O}_{7}$ in an ultrasonic bath. Grain size analyses of the fine-grained particles were subsequently carried out in a Sedigraph 5100 , which measures the dampening of a soft $x$-ray beam through a sedimentation cell containing the fine-grained suspension. 


\section{Fluvial input}

The input of fine-grained suspended sediment from the rivers was estimated on the basis of daily water samples collected with an automatic ISCO 2700 water sampler. Sample volumes were about 0.7 litres. The samples were filtered through Whatmann GF/F glass fibre filters to determine the mass concentration of suspended sediment. The filters were combusted at $500{ }^{\circ} \mathrm{C}$ to obtain a measure of organic content. The in-situ settling velocities of the fluvial sediment are determined with a Braystoke SK 110 water sampler/ analyser (Pejrup, 1988b).

\section{Salt marsh erosion}

Salt marsh erosion was estimated from repeated levellings of the eroding marsh cliffs at selected sites. The levelling was carried out with a theodolite equipped with an electronic distance meter of the type Topcon. Data were stored in a solid state memory as $\mathrm{x}$ and $y$ coordinates which were later transferred to a computer for automatic drafting of the cliff shape. The retreat of the salt marsh cliff could then be determined as the area between successive levellings multiplied with the average height of the cliff.

\section{RESULTS}

Fine-grained sediment budget

\section{Areal distribution of accumulation}

Based on approximately 370 surface sediment samples a map showing the distribution of the surface sediments in the intertidal and supratidal zones was established. The map (Fig. 2) is a modification of the sediment map for the tidal basin drawn by Köster et al. (1995). The surface sediments were divided into the following four facies:

Salt marsh: containing varying amounts of sediment $>63 \mu$

(mostly more than $90 \%<63 \mu \mathrm{m}$ ).

Mud flats : containing more than $50 \%$ of sediment $<63 \mu \mathrm{m}$.

Mixed mud flats: containing $10-50 \%$ of sediment $<63 \mu \mathrm{m}$.

Sand flats: containing less than $10 \%$ of sediment $<63 \mu \mathrm{m}$.

Each facies was further subdivided into an exposed and a sheltered unit with regard to the prevailing westerly winds.

A total of fourteen sediment cores representing the above eight geomorphological units were dated by application of the ${ }^{210} \mathrm{~Pb}$ method. Four of these samples were not datable due to low contents of fine-grained sediment. The budget is therefore based on ten dated sediment cores and a thorough classification of the surface sediments. An example of a dated sediment core from the Kampen tidal flats is shown in Figure 3. The computed accumulation rates for all cores are listed in Table 1.

Accumulation rates representing each of the geomorphological units are computed either as average values of the samples taken within this unit or as single values from one core taken within the unit. The exposed mud flat unit is not represented by any dated cores because it occupies a small area only. The accumulation value for this unit was 


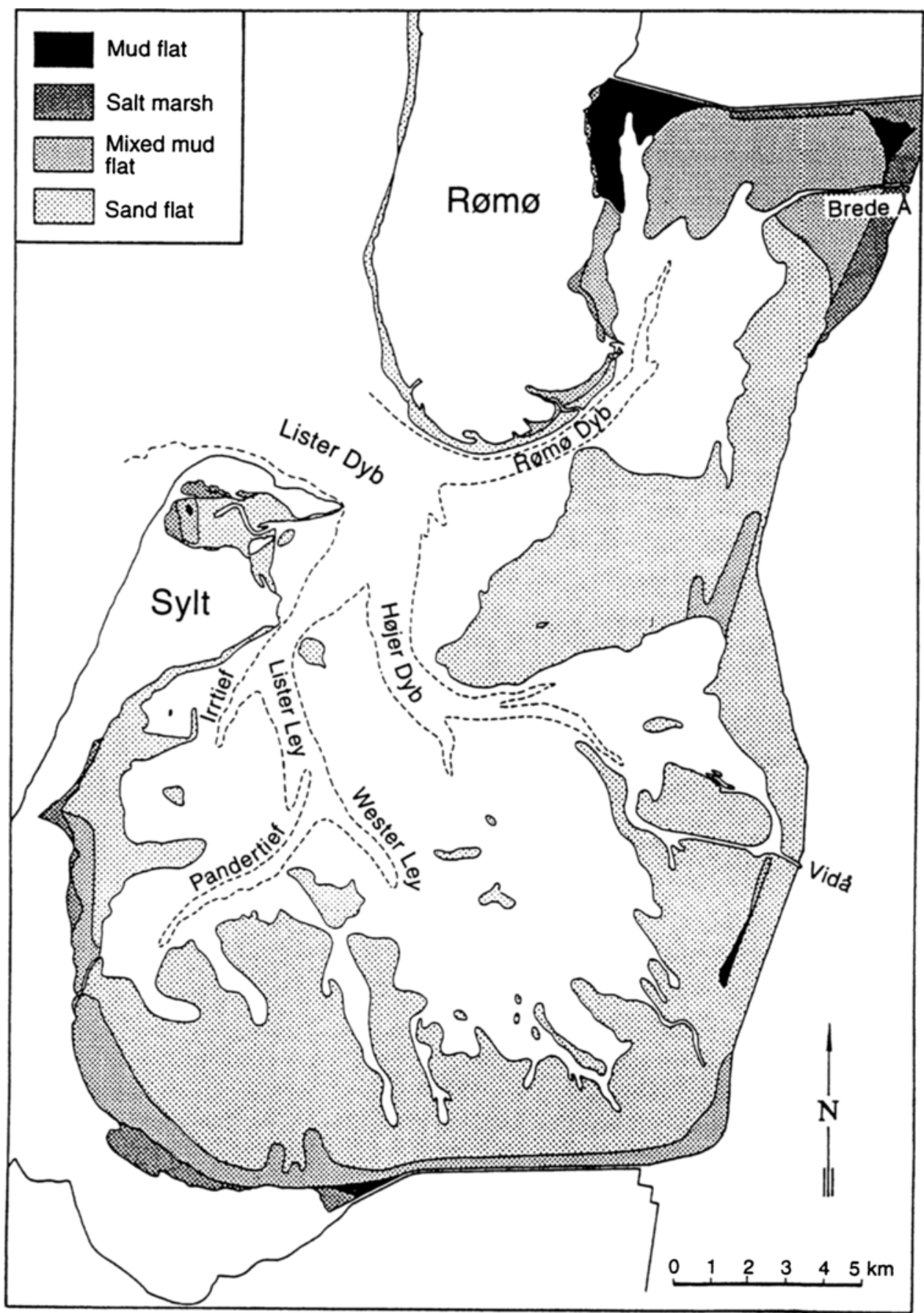

Fig. 2. Map of surface sediment distribution within the Sylt-Rømø tidal basin. This map is based on a sediment map by Köster et al. (1995) 
Kampen tidal flat

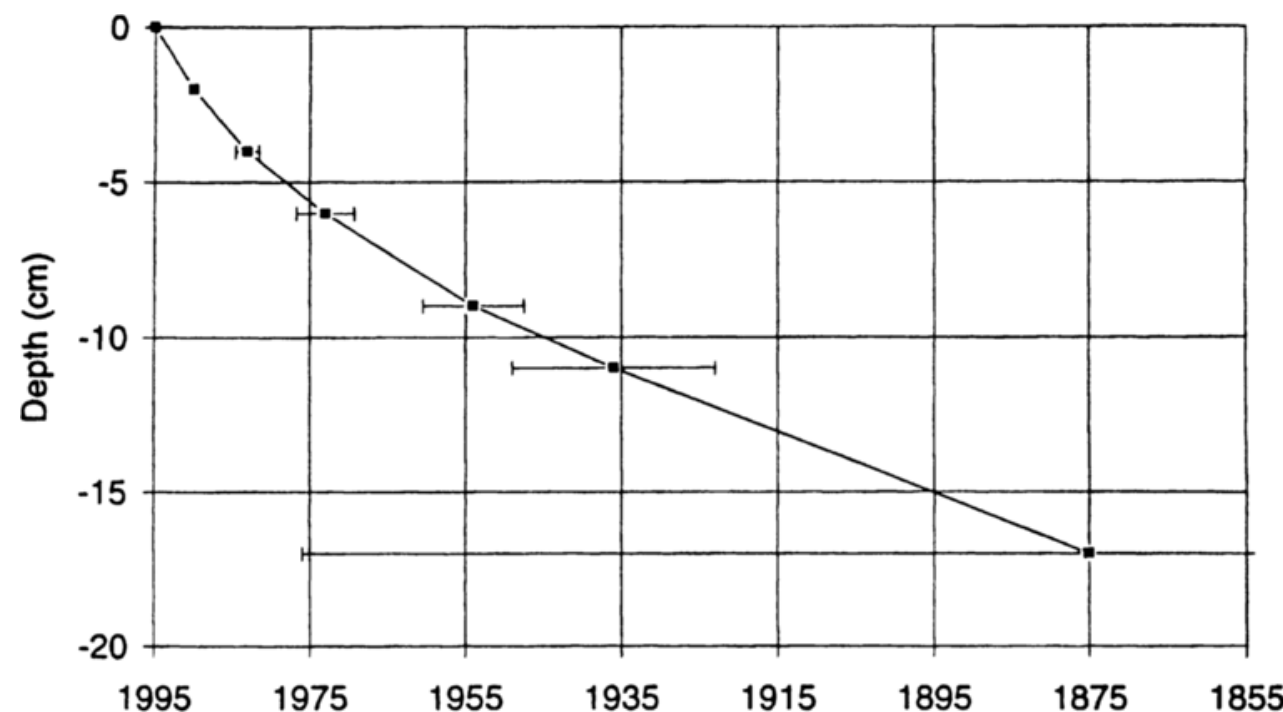

Fig. 3. Example of a sediment core dated by use of the ${ }^{216} \mathrm{~Pb}$ method

determined as the arithmetic mean of the exposed mixed mud flat unit and the sheltered mud flat unit. Furthermore, accumulation rates for the sand flats were computed on the basis of accumulation rates determined for exposed mixed mud flats after correction of the content of fine-grained sediments in the sand flat. This is a rather artificial way of estimating the fine-grained sedimentation on the sand flats, but it is considered more realistic than just disregarding these intertidal flats in which the content of fine-grained sediment is so low that the ${ }^{210} \mathrm{~Pb}$ dating method cannot be used.

Table 1. Accumulation rates from 10 different sites within the Sylt-Rømø tidal basin. Values in the table are not corrected for the sediment's sand content. A: Pejrup et al. (1995); B: Larsen et al. (1994);

C: Edelvang et al. (1993); D: Pejrup \& Bartholdy (1991); E: Breuning-Madsen (1995)

\begin{tabular}{|rlllc|}
\hline No & \multicolumn{1}{c}{ Site } & $\begin{array}{c}\text { Geomorphological } \\
\text { unit }\end{array}$ & Exposure & $\begin{array}{c}\text { Accumulation rate } \\
\text { (total kg } / \mathrm{m}^{2} / \text { year) }\end{array}$ \\
\hline 1 & Kongsmark $^{\mathrm{A}}$ & Salt marsh & Sheltered & $1.53 \pm 0.07$ \\
2 & Kongsmark $^{\mathrm{B}}$ & Mud flat & Sheltered & $3.38 \pm 0.29$ \\
3 & Rømø dam $^{\mathrm{A}}$ & Mud flat & Sheltered & $1.50 \pm 0.09$ \\
4 & Ballum $^{\mathrm{E}}$ & Salt marsh & Exposed & $0.61 \pm 0.13$ \\
5 & Ballum $^{\mathrm{C}}$ & Mixed mud flat & Exposed & $2.19 \pm 0.14$ \\
6 & Kampen $^{\mathrm{E}}$ & Mixed mud flat & Sheltered & $1.93 \pm 0.17$ \\
7 & Tipkenhügel $^{\mathrm{C}}$ & Salt marsh & Sheltered & $2.45 \pm 0.37$ \\
8 & Königshafen $^{\mathrm{D}}$ & Salt marsh & Sheltered & $1.16 \pm 0.10$ \\
9 & Königshafen $^{\mathrm{D}}$ & Salt marsh & Sheltered & $0.45 \pm 0.04$ \\
10 & Königshafen $^{\mathrm{D}}$ & Mud flat & Sheltered & $5.10 \pm 0.30$ \\
\hline
\end{tabular}


The area of each geomorphological unit was measured from the sediment map. The results, together with the total sediment accumulation rates, are listed in Table 2 . A net budget for the fine-grained sediment was then determined by multiplying the accumulation rates with their respective areas. The resulting accumulation, corrected for mean content of fine-grained sediment, amounts to about $58 \cdot 10^{3}$ t/year (Table 2). It appears that the major part of the fine-grained sediment accumulating in the Sylt-Rømø tidal basin is found on the mud flats and mixed mud flats. The salt marsh areas accumulate a significant amount of the fine-grained sediment deposited during extreme high water levels, e.g. during storm surges. Finally, it is shown that the accumulation of fine-grained sediment on the sand flats accounts for about $13 \cdot 10^{3}$ t/year due to the large area this geomorphological unit occupies in the tidal basin.

Table 2. Classification and total accumulation of fine-grained sediment in Sylt-Rømø tidal basin. Classification of each unit is based on the contents of fine-grained sediment : sand flat $<10 \%$; mixed mud flat : $10-50 \%$; and mud flat $>50 \%$

\begin{tabular}{|lcccc|}
\hline Depositional environment & $\begin{array}{c}\text { Area } \\
\left(\mathrm{km}^{2}\right)\end{array}$ & $\begin{array}{c}\text { Accumulation rate } \\
\left(\mathrm{kg} / \mathrm{m}^{2} / \text { year }\right)\end{array}$ & $\begin{array}{c}\text { Average } \\
(\%<63 \mu \mathrm{m})\end{array}$ & $\begin{array}{c}\text { Accumulated } \\
\text { sediment } \\
\text { (t/year })\end{array}$ \\
\hline Salt marsh sheltered & 4.9 & 1.6 & 94 & 7400 \\
Salt marsh exposed & 5.6 & 0.6 & 50 & 1700 \\
Mud flat lee & 4.1 & 3.3 & 73 & 9900 \\
Mud flat exposed & 1.3 & 2.7 & 88 & 3100 \\
Mixed mud flat sheltered & 20.4 & 2.0 & 29 & 12000 \\
Mixed mud flat exposed & 18.6 & 2.2 & 25 & 10400 \\
Sand flats I & 25.0 & 2.2 & 5 & 1100 \\
Sand flats II & 110.0 & 2.2 & - & 12100 \\
Total supra-tidal & 10.5 & - & - & 48100 \\
Total intertidal & 179.3 & - & - & 57700 \\
Total area of accumulation & 189.8 & - & & \\
\hline
\end{tabular}

\section{Sediment sources}

\section{Fluvial input}

Suspended sediment samples were collected in the rivers Brede $\AA$ and Vidå over the 3 years from 1992 to 1994. The suspended sediment concentration in these samples was determined as described earlier and sediment discharge was computed by multiplying suspended concentration with daily mean values of the water discharge determined from the relationship between water level and measured discharge (Sønderjyllands Amtsråd, 1993, 1994, 1995). The fluvial input averaged over the three years is shown in Table 3. These mean values are based on 3 years of measured, suspended sediment transport ranging from $11 \cdot 10^{3}$ to $22 \cdot 10^{3}$ t/year transported into the Sylt-Rømø tidal basin. The mean value over the investigation period was $17.3 \cdot 10^{3} \mathrm{t} /$ year. Approximately $3 / 4$ of this amount originates from Vidå and the remaining $1 / 4$ from Brede $\AA$. Approximately $1 / 3$ of the supplied suspended matter was organic, corresponding to $6 \cdot 10^{3} t$ year. According to findings by van Es (1977), it is assumed that $90 \%$ of the supplied organic matter is min- 
Table 3. Average values for the investigation period 1992-94 of fluvially supplied fresh water

\begin{tabular}{|lccc|}
\hline & Brede $\AA$ & Vidả & Total \\
\hline Discharge $\left(\mathrm{m}^{3} / \mathrm{sec}\right)$ & 6.7 & 17.0 & 23.7 \\
Suspended sediment concentration $(\mathrm{mg} / \mathrm{l})$ & 19.2 & 22.4 & 21.5 \\
Organic matter $(\%)$ & 39.0 & 34.2 & 35.5 \\
Total suspended transport (t/year) & 4600 & 12700 & 17300 \\
Total fresh water discharge $\left(10^{6} \mathrm{~m}^{3} /\right.$ year) & 210 & 524 & 734 \\
\hline
\end{tabular}

eralized, thus leaving only about $10 \%$ or $600 \mathrm{t}$ of organic matter for permanent deposition.

Furthermore, although the water samples in the rivers were collected at the surface, some of the suspended particles have equivalent settling diameters $>63 \mu \mathrm{m}$ as shown by the in-situ settling tube analyses. An example of such an analysis is given in Figure 4 . For the Brede $\AA$ it has been estimated that, as a yearly average, $35 \%$ of the total suspended sediment was coarser than $63 \mu \mathrm{m}$. About $11 \cdot 10^{3} \mathrm{t}$ of the supplied sediment is inorganic and about $35 \%$ of this is coarser than $63 \mu \mathrm{m}$, thus leaving about $7.5 \cdot 10^{3} \mathrm{t}$ of inorganic matter for deposition. The total retained fine-grained fluvial input must therefore be reduced from $17 \cdot 10^{3}$ t/year to $8 \cdot 10^{3}$ t/year.

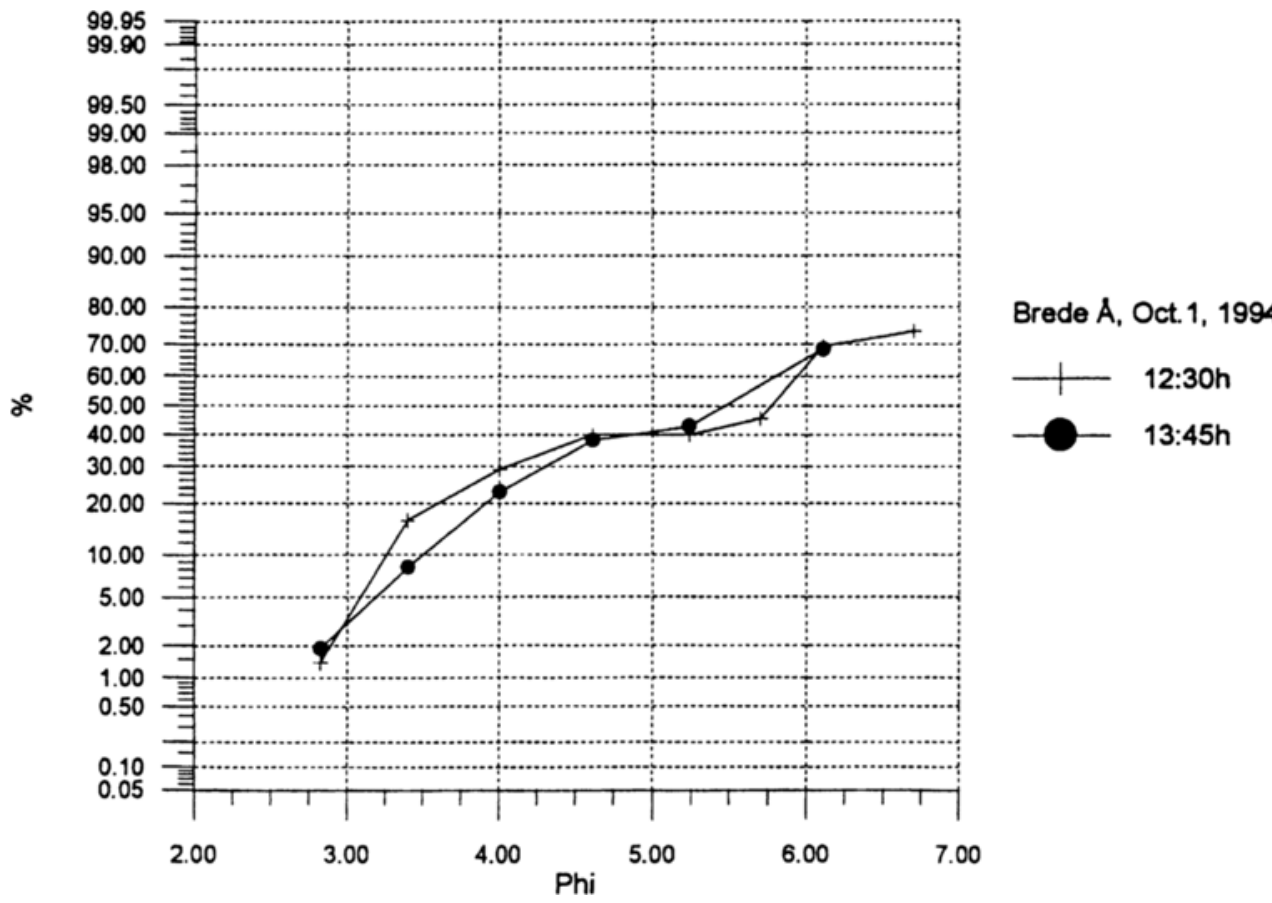

Fig. 4. Sediment grading curve for suspended sediment collected in Brede $\AA$. The horizontal axis indicates the equivalent settling diameter for the suspended sediment 


\section{Salt marsh erosion}

The results of the levelling measurements of the eroding salt marsh cliffs are shown in Tables 4 and 5. Six test stretches were selected and levelled in the years 1992, 1993 and 1994, allowing two yearly erosion rates to be estimated. The amount of sediment eroded was calculated as:

$$
\mathrm{E}=\mathrm{C}_{\mathrm{e}} / \mathrm{M}_{\mathrm{e}}
$$

Where $E$ is the eroded amount of sediment $\mathrm{m}^{3} / \mathrm{m}$

$\mathrm{C}_{\mathrm{e}}$ is the calculated erosion in $\mathrm{m}^{3}$ and

$M_{e}$ is the measured length in $m$.

The total erosion was calculated by multiplying the estimated $E$ value with the total length of the erosional salt marsh of the different test sites. Finally, this figure was multiplied with the computed bulk densities of the investigated salt marshes. This amount was further corrected for the content of sediment coarser than $63 \mu \mathrm{m}$ and then extrapolated to the whole length of erodible salt marshes in the area (Table 6). From Table 6 it can be seen that in 1992-93 about $2.8 \cdot 10^{3}$ t/year were eroded from the salt marshes fringing the tidal basin, whereas in 1993-94 about $2.1 \cdot 10^{3}$ t/year were eroded. As evident from the values listed in Tables 4 and 5, this figure is fairly constant along the investigated stretches from year to year. On this basis, a mean value of $2.5 \cdot 10^{3} \mathrm{t}$ /year of sediment eroded along the salt marsh was estimated.

Table 4. Salt marsh erosion measurements 1992-1993

\begin{tabular}{|lcccccc|}
\hline Site & $\begin{array}{c}\text { Test } \\
\text { length } \\
(\mathrm{m})\end{array}$ & $\begin{array}{c}\text { Measured } \\
\text { erosion } \\
\left(\mathrm{m}^{3}\right)\end{array}$ & $\begin{array}{c}\text { Total } \\
\text { length } \\
(\mathrm{m})\end{array}$ & $\begin{array}{c}\text { Relative } \\
\text { erosion } \\
\left(\mathrm{m}^{3} / \mathrm{m}\right)\end{array}$ & $\begin{array}{c}\text { Bulk } \\
\text { density } \\
\left(\mathrm{kg} / \mathrm{m}^{3}\right)\end{array}$ & $\begin{array}{c}\text { Total } \\
\text { erosion } \\
\text { (tonnes })\end{array}$ \\
\hline Gross (east) & 410 & 74.6 & 1000 & 0.182 & 1040 & 189.2 \\
Gross (west) & 300 & 57.9 & 1300 & 0.193 & 980 & 245.9 \\
Keitum & 230 & 128.0 & 1125 & 0.557 & 1120 & 701.2 \\
Königshafen & 80 & 22.6 & 575 & 0.283 & 1010 & 164.1 \\
Kongsmark & 250 & - & 1000 & - & 1040 & - \\
Havneby & 250 & - & 1500 & - & 1280 & - \\
\hline
\end{tabular}

Table 5. Salt marsh erosion measurements 1993-1994

\begin{tabular}{|lcccccc|}
\hline Site & $\begin{array}{c}\text { Test } \\
\text { length } \\
(\mathrm{m})\end{array}$ & $\begin{array}{c}\text { Measured } \\
\text { erosion } \\
\left(\mathrm{m}^{3}\right)\end{array}$ & $\begin{array}{c}\text { Total } \\
\text { length } \\
(\mathrm{m})\end{array}$ & $\begin{array}{c}\text { Relative } \\
\text { erosion } \\
\left(\mathrm{m}^{3} / \mathrm{m}\right)\end{array}$ & $\begin{array}{c}\text { Bulk } \\
\text { density } \\
\left(\mathrm{kg} / \mathrm{m}^{3}\right)\end{array}$ & $\begin{array}{c}\text { Total } \\
\text { erosion } \\
\text { (tonnes) }\end{array}$ \\
\hline Gross (east) & 410 & 73.7 & 1000 & 0.180 & 1040 & 187.2 \\
Gross (west) & 300 & 54.1 & 1300 & 0.180 & 980 & 229.3 \\
Keitum & 230 & 120.4 & 1125 & 0.523 & 1120 & 659.0 \\
Königshafen & 80 & 17.9 & 575 & 0.224 & 1010 & 130.1 \\
Kongsmark & 250 & 60.2 & 1000 & 0.241 & 1040 & 250.6 \\
Havneby & 250 & 21.8 & 1500 & 0.087 & 1280 & 167.0 \\
\hline
\end{tabular}


Table 6. Total and mean erosion of erodible salt marsh measured by the survey method

\begin{tabular}{|cccccc|}
\hline Year & Total erosion & $\begin{array}{c}\text { Length of } \\
\text { test areas } \\
(\mathrm{m})\end{array}$ & $\begin{array}{c}\text { Total length of erodible } \\
\text { salt marsh } \\
(\mathrm{m})\end{array}$ & $\begin{array}{c}\text { Average } \\
(\%<63 \\
\mu \mathrm{m})\end{array}$ & $\begin{array}{c}\text { Supply } \\
(\mathrm{t} / \text { year })\end{array}$ \\
\hline $1992-93$ & 1300 & 4000 & 10000 & 85 & 2800 \\
$1993-94$ & 1600 & 6500 & 10000 & 85 & 2100 \\
mean & - & - & 10000 & 85 & 2500 \\
\hline
\end{tabular}

\section{Atmospheric input}

The atmospheric contribution to the fine-grained sediment budget was calculated from published data. An average deposition rate of $0.055 \mathrm{~g} / \mathrm{m}^{2} /$ day was measured by Lufthygienische Überwachung (1992: pers. comm.) based on three measuring stations near Brunsbüttel. This gives a yearly input of $20 \mathrm{t} / \mathrm{km}^{2} /$ year to the Sylt-Rømø tidal basin. Studies in the North Sea area carried out by McCave (1973) yielded average atmospheric deposition rates of $2.8 \mathrm{t} / \mathrm{km}^{2} /$ year. This rather low value is supported by Broecker et al. (1958) who found deposition rates of $2.0 \mathrm{t} / \mathrm{m}^{2} /$ year for the Mid-Atlantic ridge.

Based on data presented by Schulz (1993), Larsen et al. (1996) estimated a total wet and dry deposition rate of undissolvable matter to $2.2 \mathrm{t} / \mathrm{km}^{2} /$ year at Westerhever Lighthouse on the peninsula of Eiderstedt about $60 \mathrm{~km}$ south of the Sylt-Rømø tidal basin. It is likely that high contents of dissolvable salts, such as ammonia, nitrate and sodium chloride, explain the high values of atmospheric deposition at Brunsbüttel which incidentally is an industrial site. Such compounds could easily contribute $3-10 \mathrm{t} / \mathrm{km}^{2} /$ year, depending on the distance between the measuring station and the sea. It was thus decided to use the values of Schulz (1993) to estimate the atmospheric deposition in the Sylt-Rømø tidal basin. On this basis the atmospheric input to the fine-grained sediment budget amounts to $0.9 \cdot 10^{3} \mathrm{t} /$ year.

\section{Primary production}

The contribution from both benthic and pelagic primary production has also been estimated on the basis of published data. Cadée \& Hegeman (1974) found values of 100 $( \pm 40) \mathrm{g} \mathrm{C} / \mathrm{m}^{2} /$ year for the benthic primary production - a value that is supported by results from the Dollard estuary presented by van Es (1977), who estimated a benthic primary production of $116 \mathrm{~g} \mathrm{C} / \mathrm{m}^{2} /$ year. Asmus \& Asmus (1985) found values of $150 \mathrm{~g}$ $\mathrm{C} / \mathrm{m}^{2} /$ year for the benthic primary production in Königshafen, and Bruns et al. (1995) found a mean value of $111( \pm 35) \mathrm{g} \mathrm{C} / \mathrm{m}^{2} /$ year computed for the whole of Sylt-Rømø tidal basin. Furthermore, van Es (1977) found a pelagic primary production of $7.5 \mathrm{~g} \mathrm{C} / \mathrm{m}^{2} /$ year. On the basis of the above data it was decided to use a primary production of $118 \mathrm{~g}$ $\mathrm{C} / \mathrm{m}^{2} /$ year, for the computation of the organic input to the sediment budget. This is equivalent to about twice the amount of organic matter, corresponding to $236 \mathrm{~g} / \mathrm{m}^{2} / \mathrm{year}$. At least $90 \%$ of this is mineralized before accumulation (van Es, 1977) which leaves $10 \%$ as input to the net budget of fine-grained sediment. For a tidally influenced area of $390 \mathrm{~km}^{2}$ this corresponds to about $9 \cdot 10^{3}$ t/year from primary production. 


\section{Relative importance of different sediment sources}

The net budget of fine-grained sediment in the Sylt-Rømø tidal basin can now be divided according to the different sediment sources. This is shown in Table 7 . The total amount of fine-grained sediment accumulated in the tidal basin amounts to a yearly average of $58 \cdot 10^{3} \mathrm{t}$.

Table 7. Fine-grained sediment budget of the Sylt-Rømø tidal basin. The contribution from the different sediment sources is rounded to thousands

\begin{tabular}{|lcc|}
\hline Sediment source & $\begin{array}{c}\text { Net accumulation } \\
\text { (t/year) }\end{array}$ & $\begin{array}{c}\text { Relative contribution } \\
(\%)\end{array}$ \\
\hline Rivers & 8000 & 14 \\
Primary production & 9000 & 15 \\
Salt marsh erosion & 3000 & 5 \\
Atmospheric deposition & 1000 & 2 \\
North Sea (residue) & 37000 & 64 \\
Total & 58000 & 100 \\
\hline
\end{tabular}

It would appear that fluvial input and primary production are of equal amounts, contributing $14 \%$ and $15 \%$ respectively. This is based on the assumption that all fluvially supplied sediment and the non-mineralized fraction of the primary production are deposited within the tidal basin. Considering this assumption, the calculated figures must be regarded as representing maximum values. The same argument applies to salt marsh erosion (5\%) and atmospheric deposition ( $2 \%$ ), the latter being of only minor importance for the total net accumulation of fine-grained sediments. The contribution from the adjacent North Sea is estimated as the residue between the total accumulated amount of sediment and the sediment from other sources. In this way it is found that the North Sea contributes $64 \%$ of the net input of fine-grained sediment. Following the argumentation above, this figure must be considered a minimum value.

\section{DISCUSSION}

\section{Total accumulated sediment}

To evaluate the fine-grained sediment budget of the Sylt-Rømø tidal basin it is compared with the net budget for the Grảdyb tidal area established by Bartholdy \& PheifferMadsen (1985). These authors found a total accumulation of fine-grained sediment of $142 \cdot 10^{3} \mathrm{t} /$ year, half of which was deposited on the salt marsh and half on the mud flats. In the present study, an accumulation of $9 \cdot 10^{3} \mathrm{t} /$ year was estimated for the salt marsh and about $49 \cdot 10^{3} \mathrm{t}$ /year for the intertidal flats. Correcting for the different areas covered by salt marsh and intertidal flats in the two tidal areas, the average accumulation rate on the salt marshes of the Sylt-Rømø tidal basin corresponds to only half the average value of the Grådyb tidal area. Furthermore, the average accumulation rates on the intertidal flats are about 9 times higher in the Grådyb tidal basin compared to those measured for the Sylt-Rømø tidal basin. These differences can partly be explained by the higher per- 
centage of sheltered salt marshes and intertidal flats in the Grådyb tidal basin. Thus, the morphology of the tidal area is shown to be a major determinant for accumulation of finegrained sediments. This is consistent with suggestions made by Bartholdy \& PheifferMadsen (1985) who argued that accumulation rates lower than those found in the Grådyb tidal basin can be expected in more exposed tidal basins. Based on this comparison the results obtained by Flemming \& Nyandwi (1994) are likely to represent a general trend in the depositional pattern of fine-grained sediment in the Wadden Sea.

\section{Trapping efficiency}

To facilitate the comparison of fine-grained sediment accumulation in different tidal basins, Bartholdy \& Pheiffer-Madsen (1985) defined the value C as a general measure of trapping efficiency, where:

$$
\mathrm{C}=\frac{\text { yearly accumulated sediment }}{\text { yearly exchanged water volume }}
$$

In this manner different tidal basins of very different size can be compared. This concept was adapted by Larsen et al. (1996) who estimated $C$ to be $0.7 \mathrm{~g} / \mathrm{m}^{3}$ for the Königshafen tidal basin, a small subcatchment of the Sylt-Rømø tidal basin. This compares with values for Jade Bay of $1.8 \mathrm{~g} / \mathrm{m}^{3}$, Dollard $3.1 \mathrm{~g} / \mathrm{m}^{3}$ and Grådyb $1.5 \mathrm{~g} / \mathrm{m}^{3}$ (cf. Bartholdy \& Pheiffer-Madsen, 1985). The C-value computed for the Sylt-Rømø tidal basin is $0.2 \mathrm{~g} / \mathrm{m}^{3}$, suggesting that net deposition for the average volume of water exchanged with the North Sea is nine times smaller than that for the Grådyb tidal basin.

However, when calculating in this way one cannot speak of trapping efficiency with regard to water exchange with the sea because the supply from all sediment sources is included. Another index for comparison of trapping efficiency with regard to tidal exchange of sea water could be defined as:

$$
E=\frac{\text { Yearly amount of sediment deriving from the sea }}{\text { Yearly exchanged water volume }}
$$

In this way, trapping efficiency between the Grådyb and the Sylt-Rømø tidal basins can be compared, the E values being shown in Table 8.

The trapping efficiency computed in the manner suggested above can be considered a minimum value, the input from the sea being computed as the residue between total net accumulation and supply from other sediment sources. It would appear that the differences in trapping efficiencies between the Grådyb and the Sylt-Rømø tidal basin

Table 8. Relative accumulation (C) and trapping efficiency (E) for Grådyb and Sylt-Rømø tidal basins

\begin{tabular}{|lcc|}
\hline Tidal area & C value $\left(\mathrm{g} / \mathrm{m}^{3}\right)$ & E value $\left(\mathrm{g} / \mathrm{m}^{3}\right)$ \\
\hline Grådyb & 1.46 & 1.23 \\
Sylt-Rømø & 0.16 & 0.10 \\
\hline
\end{tabular}


change from a factor of nine to a factor of twelve when comparing $C$ and E-values respectively. Since sediment concentrations in the Grådyb and the Lister Dyb tidal inlets are fairly similar, the E index seems to be better suited to express the trapping efficiency of a tidal basin.

\section{CONCLUSION}

The Sylt-Rømø tidal basin is a net sink for fine-grained sediment. As a yearly average, $58 \cdot 10^{3}$ t of fine-grained sediments are deposited in the tidal basin itself and on salt marshes fringing it. About $9 \cdot 10^{3} \mathrm{t} /$ year deposit on the salt marsh and about $49 \cdot 10^{3} \mathrm{t} / \mathrm{year}$ on the intertidal flats. The main single sediment source is the North Sea, contributing $64 \%$ to the net sediment budget. Other important sources are fluvial input $(14 \%)$ and primary production $(15 \%)$. Of minor importance to the accumulation of fine-grained sediment is the erosion of salt marsh deposits (5\%) and atmospheric deposition (2\%). The trapping efficiency with regard to water exchange between the North Sea and the SyltRømø tidal basin is very low compared to that of, for example, the Grảdyb tidal basin, the Dollard estuary and Jade Bay. This result supports suggestions made by other authors that intensive diking is one major cause of diminished deposition of fine-grained sediment within a tidal basin. However, another important factor influencing deposition rates is the exposure of the intertidal flats to the prevailing westerly winds. It may therefore be concluded that the amount of fine-grained sediment deposited in a tidal basin is mainly a function of physiographical and hydrodynamical parameters and to a lesser degree of sediment availability.

Acknowledgements. This study was supported by the Federal Ministry for Education, Science, Research and Technology, Bonn, (BMBF) as part of the "Ecosystem Research in the Schleswig-Holstein Wadden Sea". The authors want to express their gratitude to all those involved in this project who have contributed to this paper by way of data, exchange of knowledge or discussions. Special thanks are due to Klaus Bayerl and Dagmar Lackschewitz for providing most of the data used for the sediment map. This is publication no. 269 of the project "Ecosystem Research Wadden Sea".

\section{LITERATURE CITED}

Appleby, P. G. \& Oldfield, F. 1978. The calculation of lead 210 dates assuming a constant rate of supply of unsupported ${ }^{210} \mathrm{~Pb}$ to the sediment. - Catena 5, 1-8.

Asmus, H. \& Asmus, R., 1985. The importance of grazing food chain for energy flow and production in three intertidal sand bottom communities of the northern Wadden Sea. - Helgoländer Meeresunters. 39, 273-301.

Bartholdy, J. \& Pheiffer-Madsen, P., 1985. Accumulation of fine-grained material in a Danish tidal area. - Mar. Geol. 67, 121-137.

Breuning-Madsen, H., (Ed.), 1995. Deposition of fine-grained sediment in the Königshafen tidal area.- Meddr. Skalling-Lab. 34, 1-39.

Broecker, W. S., Torekian, K. K. \& Heerzen, B. C., 1958. The relation of deep sea sedimentation rates to variations in climate. - Am. J. Sci. 256, 503-517.

Bruns, R., Hollinde, M. \& Meyer-Reil, L.-A., 1995. Untersuchung zu mikrobiellen Nährstoffumsetzungen. SWAP Teilprojekt 2.1/3.4b. Bundesministerium für Forschung und Technologie, Bonn, $114 \mathrm{pp}$.

Cadée, G. C. \& Hegeman, J., 1974. Primary production of the benthic microflora living on tidal flats in the Dutch Wadden Sea. - Neth. J. Sea Res. 8, 260-291.

Davis, J. L. H., 1964. A morphogenic approach to world shorelines. - Z. Geomorph. 8 (Sonderh.), $127-142$. 
Dronkers, J., 1986. Tide-induced residual transport of fine-sediment. In: Physics of shallow estuaries and bays. Ed. by J. van de Kreeke. Springer, New York, 228-244.

Edelvang, K., 1995. Falddiametre af flokkuleret sediment: variationen over en tidevandsperiode. In: Præentationer ved det 8. Danske Havforskermøde. Ed. by B. Larsen. Fyns amt, Odense, $20-24$.

Edelvang, K. \& Austen, I., 1997. The temporal variation of flocs and fecal pellets in a tidal channel. - Estuar. coast. Shelf Sci. 44, 361-367.

Edelvang, K., Larsen, M. \& Pejrup, M., 1993. Deposition of fine-grained sediment in the Sylt-Rømø tidal area. SWAP Teilprojekt B 4.2. Bundesministerium für Forschung und Technologie,.Bonn, 20 pp.

Eisma, D. \& Irion, G., 1988. Suspended matter and sediment transport. In: Pollution of the North Sea. An assessment. Ed. by W. Salomons, B. L. Bayne, E. K. Duursma \& U. Förstner. Springer, Berlin, 20-35.

El-Daoushy, F., 1988. A summary on the lead-210 cycle in nature and related applications in Scandinavia. - Environ. int. 14, 305-319.

Es, F. B. van, 1977. Preliminary carbon budget for a part of the Ems estuary: The Dollard. - Helgoländer wiss. Meeresunters. 30, 283-294.

Flemming, B. W. \& Nyandwi, N., 1994. Land reclamation as a cause of fine-grained sediment depletion in backbarrier tidal flats (southern North Sea). - Neth. J. aquat. Ecol. 28, 299-307.

French, J. R., Spencer, T., Murray A. L. \& Arnold N. S., 1994. Geostatistical analysis of sediment deposition in two small tidal wetlands, Norfolk, U. K. - J. coast. Res. 11, 308 321.

Haven, D. S. \& Morales-Alamo, R., 1972. Biodeposition as a factor in sedimentation of fine suspended solids in estuaries. - Mem. geol. Soc. Am. 133, 121-130.

Hayes, M. O., 1979. Barrier island morphology as a function of tidal and wave regime. In: Barrier Islands. Ed. by S. P. Leatherman. Acad. Press, New York, 1-27.

Köster, R., Austen, G., Austen, I., Bayerl, K.-A. \& Ricklefs, K., 1995. Sedimentation, erosion und biodeposition. SWAP Teilprojekt 1.2b/3.1. Abschlußbericht. Christian-Albrechts-Univ. Kiel, FTZ, Büsum, 89 pp.

Larsen, M., Edelvang, K. \& Pejrup, M., 1996. A fine-grained sediment budget for a small tidal area, Königshafen, Sylt, Germany. - Geogr. Tidsskr. 96, 10-19.

Larsen, M., Pejrup, M. \& Edelvang, K., 1994. Deposition of fine-grained sediment in the Sylt-Rømø tidal area. SWAP Teilprojekt B 4.2. Bundesministerium für Forschung und Technologie, Bonn, $27 \mathrm{pp}$.

Leonard, L. A., Hine, A. C. \& Luther, M. E., 1994. Surficial sediment transport and deposition processes in a Juncus roemerianus marsh, west-central Florida. - J. coast. Res. 11, 322-336.

McCave, I. N., 1973. Mud in the North Sea. In: North Sea science. Ed. by E. D. Goldberg. MIT Press, Cambridge, Mass., 75-100.

Pejrup, M., 1988a. Suspended sediment transport across a tidal flat. - Mar. Geol. 82, $187-198$.

Pejrup, M., 1988b. Flocculated suspended sediment in a micro-tidal environment. - Sediment. Geol. 57, 249-256.

Pejrup, M., 1991. The influence of flocculation on cohesive sediment transport in a microtidal estuary. - Mem. Can. Soc. Petroleum Geologists 16, 283-290

Pejrup, M. \& Bartholdy, J., 1991. Deposition of fine-grained sediment in the Königshafen tidal area. SWAP Teilprojekt B 4.2. Vorlaufprojekt. Bundesministerium für Forschung und Technologie, Bonn, 19 pp.

Pejrup, M., Larsen, M. \& Edelvang, K., 1995. Deposition of fine-grained sediment in the Sylt-Rømø tidal area. SWAP Teilprojekt B 4.2. Bundesministerium für Forschung und Technologie, Bonn, 45 pp.

Pheiffer-Madsen, P. \& Sørensen, J., 1979. Validation of the lead-210 dating method. - J. radioanalyt. Chem. 54, 39-48.

Postma, H., 1967. Sediment transport and sedimentation in estuarine environment. In: Estuaries. Ed. by G. H. Lauff. Am. Assn Adv. Sci., Washington, D. C., 158-179.

Schubel, J. R. \& Carter, H. H., 1984. The estuary as a filter for fine-grained suspended sediment. In: The estuary as a filter. Ed. by V. S. Kennedy. Acad. Press, Orlando, 81-105.

Schulz, M., 1993. Räumliche und zeitliche Verteilung atmosphärischer Einträge von Spurenelementen in die Nordsee. - SchrR. angew. Analyt. 17, 1-191. 
Straaten, L. M. J. U. van \& Kuenen, P. H., 1957. Accumulation of fine-grained sediment in the Dutch Wadden Sea. - Geologie Mijnb. 19, 329-354.

Straaten, L. M. J. U. van \& Kuenen, P. H., 1958. Tidal action as a cause of clay accumulation. - J. sedim. Petrol. 28, 406-413.

Sønderjyllands Amtsråd, 1993. "Afstrømningsmålinger 1992 i Sønderjyllands Amt". Sønderjyllands Amtsråd, Tønder.

Sønderjyllands Amtsråd, 1994. "Afstrømningsmålinger 1993 i Sønderjyllands Amt". Sønderjyllands Amtsråd, Tønder.

Sønderjyllands Amtsråd, 1995. "Afstrømningsmålinger 1994 i Sønderjyllands Amt". Sønderjyllands Amtsråd, Tønder. 